Mental Health Act

There is much the North can learn from the South, in particular with regard to the utilisation of meagre resources.

The development of both the east and west has reached a dizzying pace, with huge investments in both

infrastructure and social services over the past two decades.

\section{Parameshvara Deva FRCPsych} email devaparameshvara@yahoo.com alaysia is a tropical country in the heart of South East Asia, at the crossroads of the ancient east-west sea trade routes. Although independent from British colonial rule only in 1957, it has a recorded history dating back to at least the first century $C E$, when the region was already the source of valuable mineral and forest produce that found markets in China, India and further west.

Malaysia has an area of over $330000 \mathrm{~km}^{2}$, divided between Peninsular Malaysia (formerly known as West Malaysia, south of Thailand) and Sabah and Sarawak (formerly known as East Malaysia, on the island of Borneo, on which are also Brunei and Kalimantan, part of Indonesia). Ethnically, the population comprises 55\% $M$ alay and other indigenous people, 33\% Chinese and $9 \%$ Indians and other groups from South Asia. About 19 million of its 24 million inhabitants live in Peninsular Malaysia, while about 5 million live in the two states in Borneo, which have about three-fifths of the land area.
The current Mental Health Act (1989) provides for the establishment of a mental health board, which in theory regulates mental health services in the country. The Act also provides for voluntary and involuntary admission to those hospitals designated for this purpose under the Act. It also prohibits discrimination by insurance companies against persons with a mental illness. Efforts are currently being made to update the Act, in particular in the areas of safeguarding the human rights of people who have a mental illness. This, however, is low on the list of priorities in Kenya.

only a booming tourist destination but, like the nation's long-distance runners, proposes to capture, in the long run, researchers from the UK and other Euro-pean capitals. Such adventurers will be met with traditional African hospitality, which includes (these days) a mandatory hunting safari (photographic) to any of the game reserves. Sandy beaches on the coast and the snowcapped Mount Kenya come as extras. As we say in Kenya, 'To go is to see'.

\section{References}

Gatere, N., O thieno, C. J. \& Kathuku, D. M. (2002) Prevalence of tardive dyskinesia among psychiatric in-patients at Mathari Hospital, Nairobi. East African Medical Journal, 79 547-549.

\section{International collaboration}

The Royal College of Psychiatrists has a role to play in the promotion of mental health in Kenya, ranging from its participation in exchange programmes (to expose both members and the wider Kenyan public to the strengths and weaknesses of the systems in place in the two countries), as well as in its support of jo int research programmes. There is much the $\mathrm{N}$ orth can learn from the South, in particular with regard to the utilisation of meagre resources.

Traditional practitioners have skills that are yet to be researched, while drug trials can take place in (natural) settings in Kenya, where patients previously unexposed to medications are still to be found. Being a largely English-speaking population, and being only 8 hours from London by direct flight (21 a week), Kenya is not
Jenkins, R., Goldberg, D., Kiima, D., et al (2002) Classification in primary care: experience with current diagnostic systems. Psychopathology, 35, 127-131.

Kiima, D. M., N jenga, F. G., O konji, M. M., et al (2004) A Kenya mental health country profile. International Review of Psychiatry, 16, 48-53.

Maru, H. M., Kathuku, D. M. \& N detei, D. M. (2003) Substance use among children and young persons appearing in the $\mathrm{N}$ airobi juvenile court, Kenya. East African Medical Journal, 80, 598-602.

N jenga, F. G., N yamai, C. \& Kigamwa, P. (2003) Terrorist bombing at the US Embassy in Nairobi: the media response. East African Medical Journal, 80, 159-164.

N jenga, F. G., N yamai, C. N ., Kigamwa, P. A., et al (2004) Psychological reactions following the US Embassy bombing in $\mathrm{N}$ airobi. British Journal of Psychiatry, 185, 328-334.

0 thieno, C. J., O kech, V. C., O mondi, J. A., et al (2001) How Kenyan physicians treat psychotic disorders. East African Medical Journal, 78, 204-207.

World Bank (2002) World Development Report. Washington, DC: World Bank.

\title{
Psychiatry and mental health in Malaysia
}

Honorary Professor of Psychiatry, UPNG; Head of Department of Psychiatry, SSB Hospital, Kuala Belait, Brunei,

The two eastern states joined independent Malaya in 1963. They are less developed and have fewer social and health services. The widely distributed population centres in these two states are separated by numerous rivers, mountains and few roads, which poses major challenges to the provision of good medical and psychiatric services. On Peninsular Malaysia, however, the long established infrastructure of roads and communications has contributed to better development of health services. $\mathrm{N}$ onetheless, the develo pment of both the east and west has reached a dizzying pace, with huge investments in both infrastructure and social services over the past two decades.

\section{Development of health and mental health services in Malaysia}

There are few records of health services that existed in ancient times but resort to traditional, herbal and 
religio us healing must have started then. They continue to flourish today, despite modern medical and healthcare services being available nationwide. Malay, Chinese, Indian as well as vario us religious healing practices are available alongside modern medicine.

The modern healthcare system that is in use today was started under British colonial rule largely to cater for the plantation and mine workers in the rubber, palm oil and tin industries, to ensure their productivity, and the expatriate administrators. Indeed, the health service of old was known as the Estates Health Service. This service was expanded gradually to care for others in the country but was almost wholly based in the towns.

The mental health service, similarly, was reportedly started in the late 1700 s on the island of Penang to treat colonial sailors. This was later followed by the establishment of a mental hospital in the tin-mining town of Taiping in the 1800s but only in 1911 was a large (4000-bed) purpose-built mental asylum started, in Tanjong Rambutan in Perak, another tin-mining town. This was followed by another mental hospital, of 3000 beds, in Tampoi, Johore, in 1933, a 300-bed mental hospital in Penrissen Road in Kuching, and a smaller, 50bed mental hospital in Buli Sim Sim in Sandakan, Sabah. There was reported to be only one expatriate psychiatrist in the Central Mental Hospital in Tanjong Rambutan in 1911, and this remained the case for most of the time until independence from British colonial rule in 1957. At independence there were about 1000 medical doctors, of all categories, in the country. There were certainly no local psychiatrists and very few specialists in other fields. Mental healthcare was wholly based on institutions and was custodial in nature.

\section{Post-independence development of mental health training and services}

At independence, Malaysia had no medical school and only a branch campus of the University of Malaya in Singapore. D octors were trained in Singapore, Sri Lanka, India, Australia or other Commonwealth countries. In 1964, with the setting up of the country's first medical school at the country's first university, the U niversity of Malaya, local training started. Fortunately, the first medical school in the country was blessed with a strong foundation. The Department of Psychological Medicine taught psychiatry in 10 weeks of clerkship. The students were also examined in psychiatry in their final year. This strong presence of psychiatry in the medical curriculum has set the pace for the training of all doctors in the basics of mental health. The model has largely been followed by the seven public medical schools that followed, and contributed in no small way to the general improvement in the detection and treatment by primary care doctors of mental illness in settings other than psychiatric clinics.

In 1973 the first three doctors started training in postgraduate psychiatry in the U niversity of Malaya, to gain their Masters in Psychological Medicine (MPM). This 2-year training programme involved course work, a dissertation and the writing up of six cases treated by the trainee. Since 1988 this has been expanded to a 4year Masters programme. Today there are three such training programmes in three universities, which together produce some 10-15 psychiatrists per year for the country. The total number of psychiatrists in the country today exceeds 170 , of whom about 80 are employed by the Ministry of $\mathrm{H}$ ealth, in all states in the country. Many work in the eight public and four private medical schools. There are about 15-20 trainees in psychiatry entering training every year.

In 1958 the first general hospital psychiatric unit was started in Penang, almost in the very place where the country's first recorded mental hospital was sited about 180 years earlier. This was a major change from the institution-based services for people with a mental illness that was in existence in British times. With major revisions in healthcare that followed independence, and emphasis on community care and rural healthcare, the district or general hospital psychiatric units started to come on stream and efforts at deinstitutionalisation began.

\section{Service development in mental health}

The move to short-stay psychiatric care based in general hospitals was slow because doctors regarded the large mental hospitals as the 'real' treatment agencies for those who were mentally ill. This often kept the units in general hospitals as mere way-stations for patients to be transferred to the two large mental institutions, which were overflowing, with 4000-5000 patients each in 1970. The shortage of psychiatrists - there were only about 17 in 1977 - meant that although there were by then four mental hospitals and about 10 general hospital units, many were not staffed by trained psychiatrists. With the country's economy expanding and shifting from producing primary commodities (whose prices were unpredictable) to producing manufactured goods for export, more resources were available to improve the health services, including mental healthcare. In the late 1980s there was a big push to produce psychiatrists and other specialists. Trainees in psychiatry, who then numbered two or three per year, jumped to 15-20 per year as more training centres were set up. This led to more psychiatrists for services in more parts of the country.

Today there are 32 psychiatric units in general hospitals and district hospitals, with a total of about 1000 beds for acute care. They each have between 20 and 100 beds, one to three psychiatrists, access to occupational therapists, social workers and psychiatric trained nurses, and most have community teams that visit highrisk patients at home. Most (if not all) run their own outreach clinics on a weekly or fortnightly basis in nearby health centres and hospitals that do not have psychiatrists. The two large mental hospitals have managed to bring down their numbers to 1200 and 2000 patients and the two smaller ones have 200 to 300 patients each. These mental hospitals, with just under 4000 beds combined, to day treat fewer in-patients and out-patients per year than are treated in the 1000 beds in the general or
With major

revisions in

healthcare that

followed

independence, and emphasis on community care and rural

healthcare, the district or general hospital psychiatric units started to come on stream and efforts at deinsti-

tutionalisation began.

In the late 1980s

there was a big push to produce psychiatrists and other specialists. Trainees in psychiatry, who then numbered two or three per year, jumped to 15-20 per year as more training centres were set

up. This led to

more psychiatrists

for services in

more parts of the country. 
district hospitals. The acceptance of short-stay psychiatric care in general hospitals by the population represents a major shift, which has largely been achieved not by forcible closure of mental hospitals (as has been the case in several other countries) but by the population's rejection of institutionalism as a mainstay of care.

There are small numbers of child and adolescent psychiatrists, forensic psychiatrists, liaison psychiatrists, rehabilitation psychiatrists, old age psychiatrists and substance misuse specialists, who were trained overseas, but more are being trained every year. As more medical schools come on stream, more academic departments are being set up and more research is being carried out in these departments.

The Ministry of H ealth's Family D evelo pment Division, in cooperation with the psychiatric services, has, since 1997, set up primary care services for people with a mental illness and over 1000 nurses and doctors in primary care help in this care. There are also over 40 day treatment centres for rehabilitation. Rehabilitation itself has changed from work therapy and vegetable farming based at hospital services to social, psychological and occupational therapies and work based on industrial subcontracts. Several of the products made by patients in the sheltered workshops are exported to other countries.

\section{Mental health of Malaysians}

\section{Rehabilitation itself has changed from work therapy and vegetable farming based at hospital services to social, \\ psychological and occupational therapies and work based on industrial subcontracts.}

\section{Substance misuse, largely of heroin, is a major prob- lem for which psychiatrists often have to advise treatment and rehabilitation agencies.} rehabilitation centres run by government agencies and numerous private and religious agencies that deal with substance misuse. Alcoholism is not as large a problem as it is in some other countries. There are currently no alcohol treatment centres in the country, although Alcoholics Anonymous groups exist in a few places.

Child abuse, violence against women and domestic violence are the focus of attention by several nongovernmental organisations and government agencies. The shortage of clinical psychologists, child psychologists, child psychiatrists and other professionals in these fields is a problem that is being addressed.

\section{Mental health associations}

The first mental health association was set up in 1969 , health professionals and others interested in mental health. Several of these associations also provide rehabilitation services in the community, besides undertaking advocacy and public education and providing advice to the Ministry of Health. The associations come under the umbrella of the Malaysian Mental $\mathrm{H}$ ealth Council and are supported by voluntary donations and fund-raising activities. Several of the mental health associations hold conventions every year, in which lay persons and professionals participate.

\section{The psychiatric profession in Malaysia}

The Malaysian Psychiatric Asso ciation (MPA) is the professional association that represents most of the psychiatrists in the country; it was founded in 1977. It has over 120 members (of whom about 20 senior members are also members or fellows of the Royal College of Psychiatrists) and its own Malaysian Journal of Psychiatry. The MPA holds national conferences (the Malaysian C onference on Psychological Medicine, now in its 10th session) every year. The MPA was a founder member of the ASEAN Federation for Psychiatry and Mental Health (AFPMH), which was formed in 1981 in Bangkok. It represents psychiatrists in the 10-member Association of South East Asian $N$ ations (ASEAN), which has a population of over 500 million. The AFPMH holds the ASEAN Congress of Psychiatry, now also in its 10th session, every 2 years in rotation in each of the ASEAN countries. Malaysia has hosted the ASEAN Congress of Psychiatry twice, with two of the rotating presidencies being filled by Malaysians. The ASEAN Congresses attract over 500 delegates from the ASEAN countries and the region, as well as Australia and Europe.

\section{Research}

Research in psychiatry in Malaysia is largely university based and usually clinical or psychopharmacological in nature. There are limited resources and expertise in the field. in Ipoh Perak. Today there are over a dozen mental health associations covering many of the states. The members are relatives of patients, consumers, mental

\section{Conclusions}

For a country that had no university, medical school or local psychiatrists, and which based all its mental healthcare in four mental institutions at independence from Britain in 1957, Malaysia has managed to develop its mental health care by moving away from custodial care towards community care. It has started training its own psychiatrists to meet the service and training needs of the country. The time is ripe to establish its own foundation of research, while expanding and consolidating basic and specialised mental healthcare.

\section{Further reading}

Parameshvara Deva, M. (2004) Malaysia: a mental health country profile. International Review of Psychiatry, 16, 167176. 